Resumido por la autora, Florence May Alsop.

El efecto de las temperaturas anormales sobre el desarrollo del sistema nervioso del embrión de gallina.

En el presente trabajo, la autora incluye una breve discusión de los métodos empleados para producir anormalidades en los animales; también revisa algunas de las causas de las anormalidades encontradas en huevos. Las conclusiones obtenidas por el presente trabajo son las siguientes: 1) El calor excesivo y una limitada cantidad de calor producen la muerte de muchos embriones de gallina y dan lugar a varias formas de anormalidades en el sistema nervioso de otros. 2). Las temperaturas elevadas aceleran el desarrollo de los embriones, mientras que las temperaturas bajas retardan el crecimiento. 3). Las anormalidades producidas en fases tempranas del desarrollo no continuan su crecimiento en los embriones de setenta y dos horas. 4). Las temperaturas comprendidas entre $\operatorname{los} 103^{\circ}$ y $\operatorname{los} 108^{\circ} \mathrm{F}$, produjeron 90 por ciento de embriones anormales; de estas anomalias $46 \%$ aparecían en la región de la cabeza y $54 \%$ en el tubo neural. 5). En huevos incubados a temperaturas comprendidas entre los $94^{\circ}$ y $101^{\circ} \mathrm{F}$., el $67^{\%}$ de los embriones eran anormales; el $17 \%$ de estas anomalias aparecian en la región cerebral y el $83 \%$ en el tubo neural. 6). Los huevos incubados a la temperatura normal produjeron casi 6.5 por ciento de embriones anormales. Muchas de estas anormalidades eran distintas de las producidas por las temperaturas anormales. El trabajo contiene tres tablas, trece figuras y una bibliografia con cincuenta y tres referencias. Richard E. Scammon, author. 


\title{
THE EFFECT OF ABNORMAL TEMPERATURES UPON THE DEVELOPING NERVOUS SYSTEM IN THE CHICK EMBRYOS ${ }^{1}$
}

\author{
FLORENCE MAY ALSOP \\ Kansas State Agricultural College, Manhattan, Kansas \\ THIRTEEN FIGURES \\ CONTENTS
}

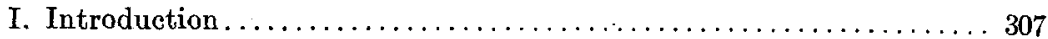

II. Discussion of literature........................... 308

A. Methods of producing abnormalities in animals........... 308

1. Abnormal heat.............................. 308

2. Hybridization............................... 308

3. Effect of chemicals.......................... 308

4. Centrifugal force........................... 309

III. Causes of abnormalities in eggs. ........................ 309

A. Abnormal ovary ................................. 309

B. Abnormal oviduct................................ 309

C. Abnormal ovary and oviduct....................... 310

IV. Determination of the age of chick embryos................. 310

A. Number of somites.............................. 310

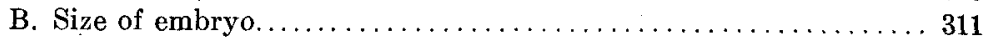

C. Length of time of incubation........................ 312

V. Method of incubation ............................... 312

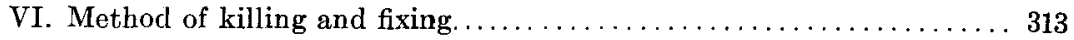

VII. Abnormalities produced by heat........................ 314

A. Effect of low temperatures upon development............. 314

B. Effect of high temperatures upon development............. 317

VIII. Results......................................... 319

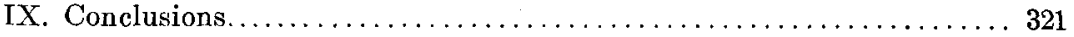

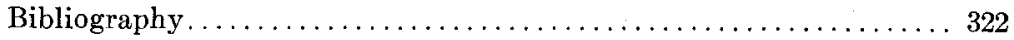

Explanation of plates............................... 326

\section{INTRODUCTION}

The work described in this paper was taken up as a result of finding abnormal chick embryos among the slides used in the

${ }^{1}$ Contribution from the Zoological Laboratory, Kansas State Agricultural College. 
embryology laboratory classes. ${ }^{2}$ Although the cause of these abnormal embryos was not known, yet they suggested the possibility of trying to produce abnormal embryos by exposing the eggs to various degrees of temperature. In the discussion which follows the writer has shown that an abnormal amount of heat may cause deformities in the nervous system of chick embryos and also that different kinds of abnormalities were produced by apparently the same condition as well as by different conditions.

\section{DISCUSSION OF LITERATURE}

Abnormalities in developing embryos have been produced in many ways. Some scientists have used an abnormal amount of heat, others have produced abnormalities by different chemicals, while still others have produced abnormal embryos by hybridization and centrifugal force.

\section{A. Methods of producing abnormalities in animals}

1. Abnormal heat. Among those who produced abnormalities by temperature variations is Greeley ('01), who found that by lowering the temperature of stentor certain well-defined structural changes took place which were not necessarily incidental to the permanent suspension of the vital functions of the cell.

King ('03) also has shown that excessive heat causes abnormalities in the toads' eggs and hastens development.

2. Hybridization. Loeb ('15) used low temperatures and heterogenous hybridization to produce blind fish embryos. Immediately after fertilization he put the eggs into a temperature of $0^{\circ}$ to $2^{\circ} \mathrm{C}$. and produced from 20 to 30 per cent abnormal embryos.

Newman ('17) also produced monsters through hybridization.

3. Effect of chemicals. Fere ('99) used the fumes of alcohol and ether and obtained many abnormal embryos. In an incu-

2 I wish to express my indebtedness and appreciation to Dr. Mary T. Harman for the use of the slides collected by her and also for her criticism of this paper. I also give acknowledgement to Dr. R. K. Nabours for his interest and encouragement in this work. 
bator set over the ventilator from the chemistry laboratory the eggs contained many abnormal chicks due to the fumes of chemicals.

Reese ('12) used narcotics as an agent in producing abnormalities in the development of hens' eggs.

4. Centrifugal force. Centrifugal force is another factor employed by some to produce abnormalities. Banta and Gortner ('14) produced accessory appendages in the amphibian larvae through the action of centrifugal force. Also Conklin ('11) describes abnormal results obtained by the action of centrifugal force upon the organization and development of the eggs of fresh-water pulmonates.

\section{CAUSES OF ABNORMALITIES IN EGGS}

Eggs that are abnormal at the time of laying probably play an important part in the development of abnormal embryos, and a certain per cent of abnormal chicks found under apparently normal external conditions are probably due to conditions through which the egg passed before it was laid. These abnormalities in the eggs may be caused by several factors, according to Parker ('06).

\section{A. Abnormal ovary}

The ovary may be abnormal or diseased. An injury may cause a breaking away of the egg from its follicle before it has ripened.

\section{B. Abnormal oviduct}

An abnormal oviduct may retain an egg until the second yolk is broken away from the follicle. In this case both yolks are sometimes encased in one shell. Schumacher ('96) explains this condition by an antiperistalsis in the oviduct. The egg retained in the oviduct has developed more than is normal at the time of laying, and the cooling of an egg at the time of the formation of the neural plates produces a large per cent of abnormalities, as will be discussed later. 


\section{Abnormal ovary and oviduct}

An abnormal ovary and oviduct are sometimes present and may produce abnormal eggs.

Eycleshymer ('07) by careful calculations has found that the temperature of the hen during the first week of incubation is from three to four degrees higher than that of the eggs under her, and if an egg is retained in an environment of $102^{\circ}$ to $104^{\circ} \mathrm{F}$. when the temperature of the eggs under a hen is found to be $98^{\circ}$ to $100^{\circ} \mathrm{F}$. it is very probable that the four degrees of extra heat will cause abnormal development. Especially was this found to be true in the first twenty-four hours of development of those eggs used in this experiment. The embryo was very susceptible to a change of a few degrees of temperature at the time when the neural tube was closing, and more so at the time when the nervous system was beginning to form.

The physiological zero, according to Lillie ('08), is that temperature below which the blastoderm undergoes no development whatever. It has been shown by Edwards ('02) that a small amount of development will take place at $21^{\circ} \mathrm{C}$, and therefore he places the physiological zero between $20^{\circ}$ and $21^{\circ} \mathrm{C}$., although $28^{\circ} \mathrm{C}$. is accepted by many authors as the degree of temperature below which no development takes place. Therefore, if $20^{\circ} \mathrm{C}$. be accepted as the physiological zero, abnormal development or growth may be caused by variations in the time of development in the hen, or by development that may take place in warm weather after the egg is laid and before it is placed under incubation.

\section{DETERMINATION OF THE AGE OF CHICK EMBRYOS}

\section{A. Number of somites}

The age of chick embryos is generally determined by the number of somites found in the early stages of development. This method is used by Lillie and others up to the end of the fourth or sixth day of incubation, but after this time the number of somites does not increase, and embryos are classified according to length. 


\section{B. Size of embryo}

There were many difficulties involved in trying to determine the age of the embryos by the greatest cervical-caudal length. The cranial and cervical flexures appeared at different stages of development in the embryos which had been incubated for the same length of time. An egg kept in the incubator for twenty-four hours under high temperatures often developed both head flexures, while another left in the incubator fortyeight hours in temperatures below normal had in a large per cent of instances formed only the cranial flexure. In a small per cent of those eggs that had been incubated for forty-eight hours below $102^{\circ} \mathrm{F}$. no flexure was formed. But in these embryos the tissue appeared to be dead, as it did not stain properly.

Abnormal flexures were present in many of the embryos. Probably the most noticeable was a bending backwards of the trunk, forming a convexity on the ventral side of the chick, which is the exact reverse of the normal development. Even the tail bud in a small number of these abnormal flexures was turned dorsally instead of ventrally.

Another condition which made it impossible to determine the age of the chicks by body length was the variation in size of the embryos which were otherwise equally developed, i.e., the number of somites was the same, the flexures were equally developed, and all had been kept in the incubator under the same degree of heat and during the same length of time. Still some were found to be 50 per cent or more larger than others. This might have been due to heredity, as it is found frequently in eggs that have been incubated in normal temperatures.

Another great hindrance to classifying the age of embryos in this experiment by either of these methods was the partial development of certain parts, for example, only one nerual plate developed in some embryos, and this development in most instances was abnormal. One side of the brain developed more than the other in a few of the embryos, while in others no brain was formed. 


\section{Length of time of incubation}

The length of time of incubation is not generally used as a basis of classification because under the best of conditions the variations in development is sufficient to prevent close grading. Fut in this paper the length of time of incubation is the only method employed to classify the age of the embryos. The comite method cannot be applied because many of the chicks do not develop somites at all. This was found to be true of those eggs which were incubated at low temperatures. A few embryos showed no somites after having been in the incubator twenty-eight hours. On the contrary, a few embryos developed accessory somites. A second row was formed lateral to and alternating with those somites of each of the first two rows of somites.

These conditions all made it difficult to use any method in determining the age of the embryos produced under abnormal temperatures. Therefore, in speaking of a twenty-four- or forty-eight-hour chick in this work the writer is referring to an embryo obtained from an egg which has been in the incubator twenty-four or forty-eight hours, respectively, regardless of its degree of development.

\section{METHOD OF INCUBATION}

The eggs used were obtained from the Poultry Department of the Kansas State Agricultural College. Each egg was marked with the number of the hen that laid it. Also the number of her mate was recorded. These records were kept in case the history of a particular chick was needed to help solve or verify certain deformities that might appear in some of the specimens, and to determine whether or not the cause of certain types of abnormalities was in the parent stock or was caused by the method of incubation. Such data were not necessary, however, because the large per cent of abnormalities was in all probability due to the method of incubating the eggs.

Three hundred and three eggs were incubated for this experiment. This does not include those abnormal embryos collected 
by Doctor Harman nor those incubated and used as a control or check upon the results obtained here.

Mr. Boyd, a student in the college, incubated one hundred and eighty-six eggs under normal conditions. He was making embryology slides for the Zoology Department, and the eggs used in his work were incubated at the same time and under the same conditions, with the exception of temperature, as those used in my work. Data were kept upon the abnormal chicks found in these eggs which were incubated at normal heat, and these results served as a control and were compared with those obtained by running the eggs at abnormal temperatures.

The eggs were all incubated in a wooden incubator, which was quite satisfactory, as the wooden frame was not susceptible, to any great extent, to a change in the temperature of the atmosphere.

The heat was furnished by a kerosene lamp. It was easily kept under control, varying not more than a degree from what was desired.

The incubators were kept in the basement of the incubating building of the poultry farm of the college. The temperature here was as cool and constant as it could be found at this time of the year, which was during the months of June and July.

The eggs were collected every hour of the day: The date and hour of laying were marked upon each shell. In no instance had the eggs been laid more than twenty-four hours before they were put into the incubator.

No eggs were incubated longer than three days, and therefore this would limit the nervous system to the early embryonic brain and neural tube. The deformities described are those found only in the brain and neural tube.

\section{METHOD OF KILLING AND FIXING}

The embryos were killed and partly fixed in the egg shell. One side of the shell was cut away; the albumen was poured out and a few drops of 10 per cent nitric acid was poured upon the embryo to kill it and partially fix it. The specimen was then cut away from the blastoderm, taken out of the shell, and the

THE ANATOMICAL RECORD, VOL. I5 NO. 6 
vitelline membrane and adhering yolk material were washed off with water. The embryos were now transferred to Bouin's fluid for further fixation. After one or two hours the embryos were placed in 70 per cent alcohol, which was changed several times during each of the next two or three days. Finally, when the picric acid was removed, the specimens for whole mounts were stained in alum carmine and mounted in balsam. Some of these embryos after being examined as whole mounts were dissolved off the slides, embedded in paraffin, and sectioned.

All of those embryos incubated for seventy-two hours were stained in borax carmine for sectioning. These were cleared in zylol and mounted in balsam.

\section{ABNORMALITIES PRODUCED BY HEAT}

The discussion which follows takes up the different kinds of abnormalities and the per cent of abnormalities which were produced in the nervous system of chick embryos. Abnormal temperatures were the only factor taken into consideration in producing these results.

\section{A. The effect of low temperatures upon development}

Different variations of temperature were applied to the eggs with different results. Low temperatures were employed first. By low temperatures is meant any degree of heat between $94^{\circ} \mathrm{F}$. and $102^{\circ} \mathrm{F}$. $\left(102^{\circ}\right.$ to $104^{\circ} \mathrm{F}$. is the temperature generally considered as normal in incubating eggs.) No eggs were incubated below $94^{\circ} \mathrm{F}$, because the per cent of embryos that died increased, and it did not prove satisfactory to run the incubator at a temperature below $94^{\circ} \mathrm{F}$.

Edwards ('02) describes a condition observed by Warynski in which the embryo is made abnormal as a result of low temperature. He says,

The yolk when cooled rises and presses the blastoderm against the vitelline membrane, to which it sticks. If this happens during the first two days, while the embryo is unprotected by the amnion, the pressure causes an arrest of development and consequent malforma- 
tions. The exact character of these, and the region of the embryo in which they occur, cannot be predicted, since it is a matter of chance as to the part of the blastoderm which will adhere to the vitelline membrane.

The above condition was not found in any of the embryos produced in this experiment. The vitelline membrane washed off easily with no part of the blastoderm adhering to it.

The abnormality which occurred most frequently as a result of incubating eggs at low temperatures was the lack of folding in of the neural plate into the neural tube for some distance above the primitive knot. The neural folds in the anterior region generally formed, although in some cases abnormally, and these folds extended posteriorly about as far as the first somites. This condition was very noticeable in those embryos which had been incubated only twenty-four hours or less (figs. 1 and 2). Also below the region of the primitive knot the plate failed to develop for a short distance. But posterior to this place the folds, in most instances, developed normally.

At the primitive knot not only was the tube formed, but extra thickenings of the walls and extra cells, apparently of ectodermal origin, nearly filled the central canal in some embryos and closing it completely in others. In still other specimens the extra tissue filled the canal in such a way that two or three neural canals were found in one neural tube. This condition was best studied in the transverse sections of the forty-eight- to seventy-two-hour chicks (figs. 11 and 12), although it was easily traced developing in the eighteen-hour chicks. The abnormality appeared here as a mass of cells developing in the region of the primitive knot. It stained more heavily than the surrounding cells and was easily followed through the series of older embryos.

In the twenty-four-hour specimens two distinct folds were beginning to form on either side of the primitive node (fig. 1). The cells at this point were apparently able to resist the lack of heat and proceeded with development, while the cells of the neural plate for a distance anterior and posterior to this region did not multiply so rapidly, and consequently the neural folds 
here were not so far developed as those in the region of the primitive node.

In the thirty-six-hour chicks the neural tube had, in most of the embryos, grown together nearly the entire length of the tube. But that part of the neural fold in which development first started stained darker than that anterior or posterior to it, showing that the tissues were thicker and that more cells had been produced in this part of the neural tube than elsewhere.

The abnormalities in the forty-eight-hour chicks did not show so distinctly as in the embryos that had been incubated a shorter length of time. Of the fifty specimens examined as whole mounts, thirty-seven appeared normal. Twelve of these seemingly normal chicks were embedded in paraffin and sectioned. The result showed eleven abnormal and one normal tube. The central canal in all eleven was either closed or partly closed with the thickening of the tube wall. The abnormality in all cases was more distinctly shown in the lumbar region than elsewhere. The canal in some specimens contained loose tissue the entire length of the tube below the hind brain.

Of the thirty embryos incubated seventy-two hours, all but one seemed normal. All of the twenty-nine sectioned transversely. One was destroyed in the process of cutting. Of the remaining twenty-eight, twenty-three had developed an abnormal neural tube, or nearly 83 per cent were abnormal. This per cent would have been larger, I think, if those embryos which had died before the seventy-two hour stage of development was reached could have been included. Nearly 23 per cent were unable to resist the low temperature or were too abnormal to live three days in a temperature which ranged from four to seven degrees below that which is found in the natural incubation of the hen.

Another abnormality produced by low temperature was the curved primitive streak (fig. 3). This was seen in the early stages of growth and developed into a tube that was abnormal in curvature (fig. 4). In the majority of these embryos the posterior third of the tube turned off to the left side instead of extending in a straight line with the anterior two thirds. This 
condition was found more often in the embryo below the age of twenty-eight hours than in the older chicks; although it was found in one forty-seven-hour specimen which was no further developed than a normal twenty-four-hour chick should be (fig. 4).

A third condition which occurred in the development of embryos under low temperatures was that of one neural plate forming into a neural fold before the other began development (fig. 7). This lack of development of the neural fold appeared more often in the younger embryos than in those older. The other neural plate finally developed after a longer period of incubation, for in but a small number of forty-eight-hour chicks did one neural fold show a development in advance of the other.

\section{B. The effect of high temperature upon development}

Embyros incubated with excessive heat developed different kinds of deformities than those described above. The amount of heat used here varied between $104^{\circ}$ to $108^{\circ} \mathrm{F}$. No eggs were incubated at a higher temperature than $108^{\circ} \mathrm{F}$. The excessive heat at this point caused nearly 25 per cent to die before the end of the period of incubation.

A large per cent of the abnormalities appeared in the brain region. The most conspicuous of these was a constriction of the neural tube below the optic vesicles. The extra amount of heat seemed to affect the rate of growth of some parts of the brain region more than other parts. The optic vesicles and midbrain region developed more rapidly than that part of the brain between them, hence the constriction or folding in followed (fig. 6). The neural tube posterior to the brain developed uniformly in most embryos, with the exception of a few which showed the extra development again in the lumbar region. This resembled very much the abnormality found in the same place in those embryos developed with low temperatures.

The higher temperatures had an effect upon the somites of the embryos which was the reverse of that caused by the lower degrees of heat. Nearly 4 per cent of the chicks incubated at 
$104^{\circ}$ to $108^{\circ} \mathrm{F}$. developed extra somites lateral to the ordinary somites (fig. 8), while in embryos produced below $101^{\circ} \mathrm{F}$. the number of somites was diminished, or in some of the twentyfour-hour chicks they did not form at all. In all the embryos but one, where the eggs had been incubated longer than twentyfour hours, the somites could be distinguished. In the one exception the egg had been incubated forty-seven hours under low temperature. The neural tube was normally developed as far as could be discerned in the whole mount, but no somites could be counted.

In none of the embryos examined could the 'accessory optic vesicles' described by Locy ('97) be found. He describes them as follows:

There exists in the brain walls of the chick and Acanthias scrial differentiations of epithelium, that take the form of vesicles, closely connected with the optic vesicles, and therefore called accessory optic vesicles. These structures are very transitory-extending over a period of three hours in the chick-and they disappear before the true brain vesicles arise with which they might otherwise become confused. Their existence supports the hypothesis that the vertebrate eycs are segmental and that the ancestors of vertebrates were primitively multiple-cyed inasmuch, the optic vesicles arise before the brain vesicles, the primitive relationship of the former is not the diverticula from the latter. This condition is secondary.

The question as to what time in the early development is the embryo most susceptible to an abnormal temperature was worked upon to a certain extent, but owing to the small number of eggs used in some instances the result could not be as conclusive as it would have been if a larger number of eggs had been used.

Eggs are put into the incubator at a low temperature, and the heat was increased several degrees for different lengths of time. Others were placed in the incubator at a certain temperature and the heat was lowered several degrees. Still other eggs were incubated at a nearly constant temperature. A few of the eggs were put into the incubator at a low degree of heat, the temperature was raised and then allowed to decrease. 
VIII. RESULTS

The following table shows that a variation of a few degrees of heat produced a large per cent of abnormalities as long as all variations were below normal.

Table showing effect of low temperatures upon developing chick embryos

\begin{tabular}{|c|c|c|c|c|c|c|}
\hline $\begin{array}{c}\text { TIME } \\
\text { IN INCU- } \\
\text { BATOR }\end{array}$ & $\begin{array}{c}\text { NUMBER } \\
\text { OF EGGS } \\
\text { USED }\end{array}$ & KINDA OF MOUNTS & $\begin{array}{l}\text { RANGE OF } \\
\text { TEMPERATURE }\end{array}$ & $\begin{array}{c}\text { NUMBER } \\
\text { OF } \\
\text { NORMAL } \\
\text { EMBRYOS }\end{array}$ & $\begin{array}{c}\text { NUMBER } \\
\text { OF AB- } \\
\text { NORMAL } \\
\text { EMBRYOS }\end{array}$ & $\begin{array}{l}\text { PER CENT } \\
\text { OF ABNOR- } \\
\text { MALITIES }\end{array}$ \\
\hline $\int 72$ & 28 & Transverse & $96-99-96$ & 5 & $23\}$ & 89 \\
\hline 72 & 1 & Whole & $96-99-96$ & 0 & $1 \int$ & ou \\
\hline $47-48$ & 50 & Whole & $95-101$ & 37 & 13 & 26 \\
\hline 48 & 12 & Transverse section & $95-101$ & 1 & 11 & 92 \\
\hline $27-32$ & 42 & Whole & $95-101.5-97$ & 21 & 21 & 50 \\
\hline 26 & 10 & Whole & $98-96$ & 0 & 10 & 100 \\
\hline 24 & 25 & Whole & $\left\{\begin{array}{l}95.5-100 \\
102.5-99\end{array}\right\}$ & 1 & 24 & 96 \\
\hline 24 & 8 & Transverse section & $\left\{\begin{array}{c}95.5-100 \\
102.5-99\end{array}\right\}$ & 1 & 7 & 87.5 \\
\hline 22 & 6 & Whole & $98-96.5$ & 3 & 3 slow & 50 \\
\hline 18 & 15 & Whole & $97-96.5$ & \multicolumn{3}{|c|}{ All slow in development } \\
\hline
\end{tabular}

The abnormalities produced in the twenty-four-hour chicks did not grow out to any noticeable degree in the seventy-twohour embryos. Or, in other words, the seventy-two-hour chicks did not outgrow the abnormalities produced in them at the twenty-four-hour stage. In the above table the per cent of abnormalities is somewhat less in the seventy-two-hour chicks than in the younger embryos. But this does not take into consideration those embryos which were dead when the shell was opened. All of these that were in a condition to be examined for structure at all were abnormal. These apparently deformed conditions may have been caused by the degeneration of the cells. Yet the eggs must have been abnormal or deformed which caused the embryos to die under the lack of heat which was resisted to a certain extent by those embryos which were alive when examined.

The eggs incubated for twenty-seven to thirty-two hours are grouped together in the table. None of these embryos were sectioned, but were examined as whole mounts. The per cent 
of abnormal chicks was the same as the per cent of normal chicks. But, as was shown in the case of the forty-eight-hour embryos, the per cent would no doubt prove much greater if these specimens had been sectioned.

No very satisfactory results were obtained from incubating eggs less than twenty-four hours under low temperatures. The embryos had not developed sufficiently to conclude whether they were normal or abnormal. Most of them showed a very low degree of development. . A slight differentiation of cells in the primitive streak had taken place.

Table showing effect of high temperatures upon developing embryos

\begin{tabular}{|c|c|c|c|c|c|c|}
\hline $\begin{array}{c}\text { TIME IN } \\
\text { INCUBATOR }\end{array}$ & $\begin{array}{l}\text { NUMBER OF } \\
\text { EGGS UEEDD }\end{array}$ & $\begin{array}{l}\text { KINDS OF } \\
\text { MOV_NTS }\end{array}$ & $\begin{array}{c}\text { RANGE OT } \\
\text { TEMPERATTURE }\end{array}$ & $\begin{array}{c}\text { NUMBER OF } \\
\text { NORMAL } \\
\text { EMBEYOS }\end{array}$ & $\begin{array}{l}\text { NUMBER OF } \\
\text { ABNOHMAL } \\
\text { EMBRYOS }\end{array}$ & $\begin{array}{c}\text { PER CENT } \\
\text { OF A BNOR- } \\
\text { MALITIES }\end{array}$ \\
\hline 48 & 18 & Whole & $105-107$ & 1 & 17 & 44 \\
\hline 28 & 16 & Whole & $103-108$ & 0 & 16 & 100 \\
\hline 24 & 14 & Whole & $105-107.5$ & 3 & 11 & 79 \\
\hline 22 & 11 & Whole & $107-107.5$ & 2 & 9 & $82-$ \\
\hline \multicolumn{4}{|l|}{ Total. } & 6 & 52 & 90 \\
\hline
\end{tabular}

Most of the embryos in this table were farther advanced in their development than an embryo ordinarily is on being in the incubator the lengths of time specified above. For example, the twenty-four-hour chicks were developed fully as much as a thirty-six hour embryo would naturally be under normal temperature (Compare figs. 5 and 7 ).

The result of Mr. Boyd's work showed that out of one hundred eighty-six eggs incubated fifteen were abnormal. But during his work the light in the incubator lamp accidentally burned out, producing out of the eighteen eggs being incubated four abnormal embryos. Excepting this set of eggs, there were one hundred seventy-one eggs, eleven of which were abnormal. Thus according to his work less than 6.5 per cent of the eggs produced abnormal chicks under apparently normal artificial conditions.

One interesting condition noted in the abnormal embryos which were produced under seemingly normal conditions, was that the deformities in these chicks were dissimilar to those 
produced by the variations in temperature. The abnormalities found in Mr. Boyd's embryos were on the whole much like some of those noticed by Doctor Harman in the laboratory slides. A few were monsters which were different from any of those found in the laboratory or produced by artificial means.

The abnormalities produced by excessive heat were located in somewhat different parts of the embryos than those produced by a limited amount of heat. This can be shown quite clearly in the table below.

\begin{tabular}{|c|c|c|c|c|c|c|}
\hline LOCATION OF ABNORMALITY & $\begin{array}{l}\text { LOW } \\
\text { TEMPERA } \\
\text { TURE. }\end{array}$ & $\begin{array}{c}\text { HIGH } \\
\text { TEMPERA- } \\
\text { TURE }\end{array}$ & $\begin{array}{l}\text { TOTAL } \\
\text { IN LOW } \\
\text { TEMPERA- } \\
\text { TORE }\end{array}$ & $\begin{array}{l}\text { TOTAL } \\
\text { IN HIGH } \\
\text { TEMPERA. } \\
\text { TURE }\end{array}$ & $\begin{array}{l}\text { PER OENT } \\
\text { IN LOW } \\
\text { TEMPERA- } \\
\text { TURE }\end{array}$ & \begin{tabular}{|} 
PER CENT \\
IN HIGH \\
TEMPERA \\
TURE
\end{tabular} \\
\hline Brain only........ & 0 & 6 & 22 & 41 & 17 & 46 \\
\hline Neural tube only.... & 83 & 12 & 105 & 47 & 83 & 54 \\
\hline Heat and tube together. & 22 & 35 & & & & \\
\hline
\end{tabular}

Some embryos had an abnormal brain only. In others the abnormalities were in the neural tube. While still others possessed an abnormal brain and neural tube. The formation of the neural folds into a tube that was abnormal occurred more frequently than any other condition. As shown in the table above, only six conditions of abnormality were located in the head region alone. Ninety-five embryos were abnormal in the neural tube. In fifty-seven of the embryos both the brain and the neural tube were affected.

\section{CONCLUSIONS}

1. Excessive heat and a limited amount of heat produced death in many chick embryos and various forms of abnormalities in the nervous system of others.

2. Excessive temperatures hastened the development of embryos, while low temperatures retarded their rate of growth.

3. The seventy-two-hour chicks did not outgrow any of the abnormalities produced in them at an earlier stage of development.

4. Temperatures between $103^{\circ}$ and $108^{\circ} \mathrm{F}$. produced 90 per cent abnormal embryos. Of these abnormalities 46 per cent were in the head region, 54 per cent were in the neural tube. 
5. In those eggs incubated at $94^{\circ}$ to $101^{\circ} \mathrm{F}$. 67 per cent were abnormal; 17 per cent of these abnormalities were in the brain region and 83 per cent were in the neural tube.

6. Incubating eggs at normal temperature produced nearly 6.5 per cent abnormal embryos. Many of these abnormalities were different from those deformities produced under abnormal temperatures.

\section{BIBLTOGRAPHY}

Allen, WM. F. 1916 Studies on the spinal cord and medulla of Cyclostomes with special reference to the formation and expansion of the roof plate and the flattening of the spinal cord. Jour. Comp. Neur., vol. 26, no. 1.

BALFoUR, F. M. 1873 On the disappearance of the primitive groove in the embryo chick. Quar. Jour. Micr. Sc., vol. 13.

Banta, Arthur M., and Gortner, Ross Aiken 1914 The production of accessory appendages and other abnormalities in amphibian larvae through the action of centrifugal force. Proc. Soc. Exp. Biol. and Med., vol. 9, no. 7.

1915 Accessory appendages and other abnormalities produced in amphibian larvac through the action of centrifugal force. Jour. Exp. Zool., vol. 18, no. 3 .

BECKWIth, T. D., AND HARBon, G. D. 1914 The poor hatching of normal eggs. Science, N. \&., vol. 40, no. 1024.

Bhown, M. C. 1910 Freak eggs. Poultry Digest, vol. 4, no. 11.

Conkin, E. G. 1911 The effects of centrifugal force upon the organization and development of the eggs of fresh water pulmonates. Jour. Exp. Zool., vol. 9, no. 2.

EDwards, C. L. 1902 The physiological zero and the index of development for the egg of the domestic fowl, Gallus domesticus. Am. Jour. Phys., vol. 6 , no. 6 .

Eycleshymer, A. C. 1897 Some observations and experiments on the natural and artificial incubation of the eggs of the common fowl. Biol. Bull., vol. 12 , no. 6 .

FÉRE, Ch, 1894 Note sur l'influence de la température sur l'incubation de l'oeuf de poule. Jour. de l'anatomic et de la physiologie. Paris, T. 30 .

1899 The influence de repos sur les effects de l'exposition préalable aux vapeurs d'alcool avent l'incubation de l'oeuf de poule. Compt. rend. Soc. de biol., T. 6.

1910 Remarques sur l'incubation des oeufs de poule prives de leur coquclle. Compt. rend, Soc. de biol., T, 52.

GuAser, OtTo 1913 On the origin of double-yolked eggs. Biol. Bull., vol. 24, no. 3 .

1916 The theory of autonomous folding in embryogenesis. Science, N. S., vol. 44, no. 1136. 
Glaser, Otтo 1917 On the mechanism of morphological differentiation in the nervous system. II. The relation between compression and the development of a series of vesicles. Anat. Rec., vol. 12, no. 2.

Goldfarb, A. J. 1913 Studies in the production of grafted embryos. Biol. Bull., vol. 24, no. 2.

Grentey, A. W. 1901 On the analogy between the effects of loss of water and lowering the temperature. Am. Jour. Phys., vol. 6, no. 2.

Hargits, Chas. W. 1899 Some interesting egg monstrosities. Zool. Bull., vol. 2 .

1912 Double eggs. Am. Nat., vol. 46, no. 549.

Harman, Mary T. 1918 Abnormalities in the chick embryo. Science, N. S., vol. 47.

Hoge, M. 4. 1915 The influence of temperature on the development of a Mendelian character. Jour. Exp. Zool., vol. 18, no. 2.

Hubbard, M. E. 1908 Some experiments on the order of succession of the scomites of the chick. Am. Nat., vol. 42 , no. 499.

KILsEy, H. 1911 Subdivision of the spinal canal in the lumbar region of chick embryos. Melbourne Proc. R. Soc., Vict., vol. 24.

King, H. D. 1903 The effect of the heat on the development of the toad's egg. Biol. Bull., vol. 5, no. 4.

LANDMAN, OtTo 1908 An open cleft in an embryonic eye of a chick of eight days. Anat. Anz., Jena, Bd. 32.

I_ECAILlon, A. 1910 Influence de la temperature sur la segmentation et la degenerescence de l'oeuf non feconde de la poule. Paris C. R. Soc. Biol., T. 68.

LEwIs, F. T. 1907 Specific characters in early embryos. Am. Nat., vol. 41, no. 489 .

Jiflie, Frank R. 1903 Experiment on the amnion and the production of anamniote embryo of the chick. Biol. Bull., vol. 5, no. 2.

1904 The development of defective embryos and the power of regeneration. Biol. Bull., vol. 7, no. 1.

1908 The development of the chick. An introduction to embryology. Henry Holt \& Co., New York.

Locy, W. A. 1897 Accessory optic vesicles in the chick embryo. Anat. Anz, Bd. 14.

LoEB, JACQUEs. 1915 The blindness of the cave fauna and the artificial production of blind fish embryos by heterogeneous hybridization and low temperatures. Biol. Bull., vol. 29, no. 1.

MaLl, F. R. 1908 A study of the causes underlying the origin of human monsters. Jour. Morph., vol. 19, no. 1.

McWhorter, J. E., AND WhIPPLe, A. O. 1912 The development of the blastoderm of the chick in vitro. Anat Rec., vol. 6, no. 3.

Montrose, T. Burrows 1911 The growth of tissues of the chick embryo outside the animal body with special reference to the nervous system. Jour. Exp. Zool., vol. 10, no. 1.

Newman, H. H. 1917 On the production of monsters by hybridization. Biol. Bull., vol. 32, no. 5 . 
O'Donoghue, C. H. 1910 Three examples of duplicity in chick embryos with a case of ovum in ovo. Anat. Anz., Jena, Bd. 37.

OLrver, K. K. 1911 On the displacement of the optic lobes during the development of the brain of the fowl. Melbourne Proc. R. Soc., Vict., vol. 24.

Parkgr, G. H. 1906 Double hens' eggs. Am. Nat., vol. 40, no. 469.

Paton, StEWaRd 1911 Experiment on developing chickens' eggs. Jour. Exp. Zool., vol. 11, no. 4.

Patterson, J. Thos. 1909 Note on accessory cleavage in the hen's egg. Science, N. S., vol. 29 , no. 715 .

Peebles, Florence 1898 Some experiments on the primitive streak of the chick. Arch. f. Entw. Mech., Bd. 7.

1903 A preliminary note on the position of the primitive streak and its relation to the chick embryo. Biol. Bull., vol. 4, no. 4.

1904 The location of the chick embryo upon the blastoderm. Jour. Exp. Zool., vol. 1, no. 3.

Peter, K. 1905 Über individuelle Variationen in der tierischen Entwicklung. Verh. Ges. deutch. Naturf., Bd. 76.

1905 Der Grad der Beschleunigung tierischer Entwicklung durch erhöhte Temperatur. Verh. Ges. deutch. Naturf., Bd. 76.

Pick, E. W. 1911 Egg abnormalities. Poultry World, vol. 7.

REESE, A. M. 1912 The effect of narcoties on the development of the hen's egg. Science, N. S., vol. 35, no. 903.

SCHAPER, AlfRed 1897 Die frühesten differenzierungsvorgänge in centralnervensystem. Axch. f. Entw. Mech., Bd. 5.

Schumacher, S. 1896 Ein Ei im Ei. Zool. Anz., Bd. 19.

STockard, C. R. 1914 The artificial production of eye abnormalities in the chick embryo. Anat. Rec., vol. 8, no. 2.

Whitman, C. D. 1883 A rare form of the blastoderm of the chick and its bearing on the question of the formation of the vertebrate embryo. Jour. Micr. Soc., vol. 23.

Yoshida, Sadao 1910 Ijo kerhai no ni rei (on two cases of abnormally developed chick embryos). Dobuts. Z. Tokyo, vol. 22. 


\section{PLATES}

All figures were drawn at table level with a no. 5 eye-piece and a $16-\mathrm{mm}$. objective, also with the aid of a camera lucida. Front lens of objective was removed for whole-mount drawings. All drawings reduced one-half. 


\section{PLATE 1}

HXPLANATION OF FIGUHES

1 Twenty-four-hour embryo, incubated at $95.5^{\circ} \mathrm{F}$. to $98.5^{\circ} \mathrm{F}$. Broken lines show plane of sections in fig. 2. $a$, through optic vesicles showing folds failing to unite; $b$, through neural plates back of fifth somite, no neural folds present; $c$, through primitive node region, neural folds formed; $d$, through neural plate posterior to primitive node region, no neural folds present; $e$, through tube forming in posterior region; $f$, through posterior region.

2 Twenty-eight-hour chick incubated at $96.5^{\circ} \mathrm{F}$. to $98.5^{\circ} \mathrm{F}$. Letters corresponding to those in fig. 1 indicate sections through these regions.

3 Twenty-four-hour chick with curved primitive streak at $a$. Incubated at $105^{\circ} \mathrm{F}$. to $107.5^{\circ} \mathrm{F}$.

4 Forty-seven-hour chick with curved neural tube at a. Folds failed to form at $b$. Incubated at $95^{\circ} \mathrm{F}$. to $97^{\circ} \mathrm{F}$. 

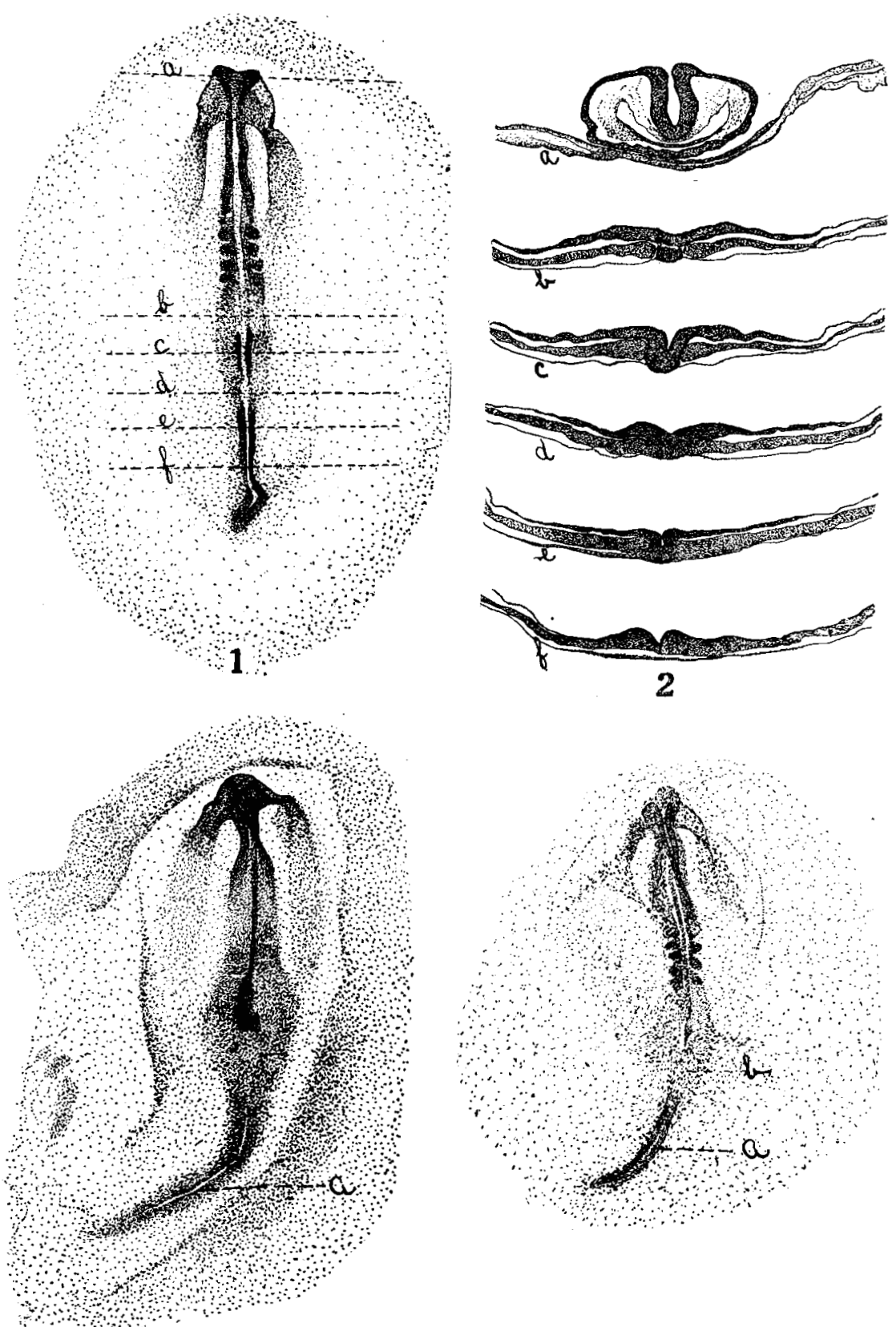

3

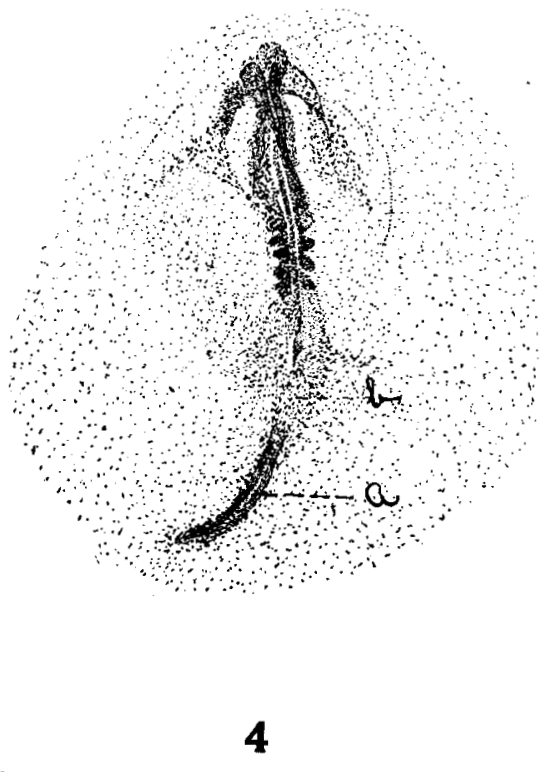




\section{PLATE 2}

EXPLANATION OF FIGURES

5 Twenty-four-hour chick. Incubated at $103.5^{\circ} \mathrm{F}$. to $108^{\circ} \mathrm{F}$. Development, equal to that of normal thirty-six-hour chick.

6 Twenty-eight-hour embryo ineubated with temperature at $103.5^{\circ} \mathrm{F}$. at beginning of incubation, raised to $108^{\circ} \mathrm{F}$. at end of fifth hour. Constriction formed below optie vesicles at $a$.

7. Twenty-four-hour chick. Incubated at $102.5^{\circ} \mathrm{F}$. to $99^{\circ} \mathrm{F}$. a, one neural fold forming in brain region; $b$, abnormal development of notochord.

8 Twenty-eight-hour embryo incubated at $103.5^{\circ} \mathrm{F}$. to $108^{\circ} \mathrm{F}$. a, accessory somites; $b$, abnormal brain; $c$, posterior limit of neural folds. 


$$
11
$$




\section{PLATE 3}

\section{EXPIJANATION OF FIGURES}

9 Twenty-nine-hour embryo incubated at $100.5^{\circ} \mathrm{F}$. to $101.5^{\circ} \mathrm{F}$. Neural tube in brain region not closed. No tube formed in remainder of body.

10 Twenty-two-hour embryo incubated at $107^{\circ} \mathrm{F}$. to $107.5^{\circ} \mathrm{F}$. Neural tube formed only in brain region.

II Transverse section of seventy-two-hour chick through posterior part of neural tube. Incubated at $97.5^{\circ} \mathrm{F}$. to $96^{\circ} \mathrm{F}$. Tube showing three central canaIs at $a$.

12 Transverse section of same embryo. a, two central canals present in neural tube.

13 Forty-eight-hour chick incubated at $96.5^{\circ} \mathrm{F}$. to $97^{\circ} \mathrm{F}$. a, extra tissue in lumbar region. 

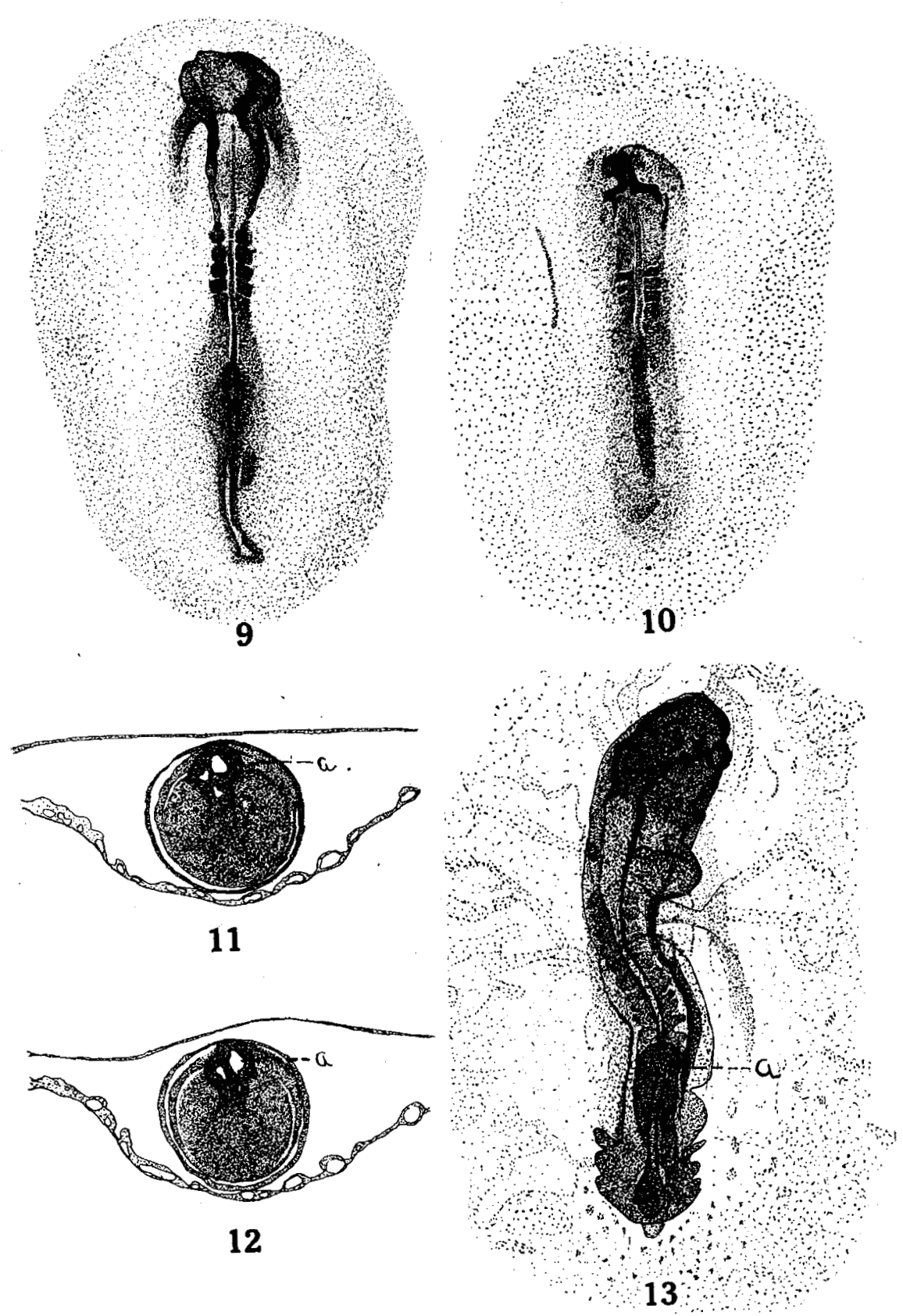